\title{
Land Use of Protected Areas in Indonesia: Between the Legal Provisions and Law Enforcement
}

\author{
Tri Andari Dahlan ${ }^{1 \mathrm{a}}$, Farena Ekky Dwi Gina Asikin ${ }^{1 \mathrm{~b}}$ \\ ${ }^{1}$ Faculty of Law, Universitas Negeri Semarang (UNNES), Indonesia \\ ${ }^{a}$ triandaridahlan@gmail.com
}

\begin{abstract}
Land requirement increases in line with populations of living things which makes the availibility of land limited. Excessive land use by ignorng environmental concerns will lead to slums that often occur in riparian zone, including Indonesia. The Comal River is the longest river in Pemalang Regency and Sragi Lama River is the shortest river in Pemalang Regency which in the land use is tree planting, public water closet, house building, and dumping of garbage. The riparian zone as a protected areas is regulated in the Regional Regulation of Pemalang Regency No.01 Year 2018 about Spatial Planning of Pemalang Regency Year 2018-2038 which explains that is prohibited to carry out activities that threaten damage and reduce the quality of river so that researchers examine how the land use arrangements at the Comal and Sragi Lama riparian zone and the law enforcement that has been carried out by the government. This study uses a qualitative method that is empirical jurisicial by conducting field research. The type of data used in this study is primary data and secondary data. This research was conducted by researching and interviewing people who used the lands in the Comal riparian zone and Sragi Lama riparian zone and analyzed with library materials, journals, laws and other sources. The results showed that land use violations at the Sragi Lama riparian zone were more found than in the Comal riparian zone and the government was not optimal in controlling and maintaining the Comal and Sragi Lama riparian zone.
\end{abstract}

Keywords—Land Use; Protected Areas; Riparian Zone

\section{INTRODUCTION}

Land requirement increases in line with populations of living things which makes the availibility of land limited. Land limitations and uncontroled population growth especially in big cities in Indonesia will have environmental impacts and other problems such as the discovery of slums and the scarcity of agricultural land as stated by Brunn and William (1983) in [5] formulate the causes of problems in urban areas as follows:

... an idea of urban problems (urban problem) due

to: ... (4) the slums and unauthorized (slums and squatter settlements), ... (10) environmental damage (environmental degradation), (11) the expansion and reduction of agricultural land (urban expansion and loss of agricultural), ...

Therefore, land use regulation is needed so that the land used by previous generations can be used by the current generation and later can be enjoyed by the next generation. Land as part of space needs a better spatial arramgement, considering that the natural resources are very diverse both available on land, at sea and in the air so that it needs to be managed in a coordinated and integrated manner with human resources and artificial resources in sustainable development patterns where the management needs to be poured into the develoment of spatial planning to make it happen so that the results of a public agreement and legality are required as technical and binding documents as well as guidance for all activities in spatial utilization [4].

Excessive land use by ignoring environmental concerns will lead to slums that often occur in riparian zone, including Indonesia especially in Pemalang Regency s one of the North Coast regions in Central Java Province. Land use of riparian zone in Pemalang Regency can be found in the Comal Riparian Zone as the longest river in Pemalang Regency and the Sragi Lama Riparian Zone as the shortest river in Pemalang Regency. The land use is tree planting, pier, public water closet, house building and dumping of garbage. Regarding land use in riparian zones, in February 2018, Pemalang Regency issued Regional Regulation of Pemalang Regency No.01 Year 2018 about Spatial Planning of Pemalang Regency Year 2018-2038 to regulate land use boundaries in the riparian zone so as not to disrupt the functon of riparian zones as protected areas. With this regulation, the authors wants to analyze how normative law works in limiting land use in riparian zone and the role of local governments and communities in returning riparian zone as protected areas.

The rules concerning the determinition of riparian zones are regulated in Regional Regulaton of Central Java Province No.09 Year 2013 about The Riparian Line, is :

1. The river with a bearing in an urban area is determined to be at least 3 meters from the outer edge of the embankment's foot along the river channel;

2. The river banks outside urban area is determined to be at least 5 meters from the outer edge of the embankmennt along the river channel;

3. The river is not bearing in urban areas is determined :

a. Minimum of 10 meters from the left and right edges of the riverbed along the river channel, in terms of the depth equal to 3 meters. 
b. At least 15 meters from the left and right edges of the riverbed along the river channel, in terms of the depth the river more than 3 meters to 20 meters; and

c. At least 30 meters from the left and right edges of the river channel, in terms of the depth of the river more than 20 meters.

4. The river with no shoulders outside the urban area consist:

a. A large river with a watershed area greater than 500 square kilometers is determined to be at least 100 meters from the left and right edges of the riverbed along the river channel; and

b. A small river with a watershed area of less than or equal to 500 square kilometers is determined at least 50 meters from the left and right edges of the riverbed along the river channel.

Article 132 paragrah (3) letter b of Regional Regulation of Pemalang Regency No.01 Year 2018 about Spatial Planning of Pemalang Regency Year 2018-2038 that land use boundaries in riparian zones are as follows:

1. Allowed space utilization for open spaces green;

2. Permitted natural tourism activities with conditions that do not interfere with river water quality;

3. Allowed conditional installation of billboards, warning counseling boards, security signs;

4. Allowed conditional installation of electrical wiring, telephone cables and drinking water pipes;

5. Permitted to be limited to the establishment of buildings to support the functions of river management, recreational parks, docks, energy facilities and other functions that require the location of the river bank with the provisions of the legislation;

6. Permitted to be limited to settlements which at the time this Regional Regulation was established already existed with the Regional Government or the institution authorized to move; and

7. Prohibited activities that threaten damage and reduce the quality of the river.

Through regulations on restrictions on land use in riparian zones, it is hoped that Regional Government of Pemalang Regency will control and maintain riparian zone as protected areas in accordance with applicable law. The problems examined related to law enforcement against land use violations in the riparian zone are:

1. How is land use in the Comal Riparian Zone and Sragi Lama Riparian Zone?

2. How is the role of Regional Government of Pemalang Regency in law enforcement against land use violations in the Comal Riparian Zone and Sragi Lama Riparian Zone?

\section{RESEARCH METHOD}

In this research the approach method used is a qualitativedescriptive approach. Descriptive research is a rstudy intended to gather information about the status of an existing phenomenon, namely the state of symptoms according to what it was at the time the research was conducted [1]. The authors use empirical juridical research which is reviewingthe applicable legal provisions and what happens in reality in the community.Data sources used in this research are primary data obtained from interviews, observation and documentation and secondary data obtained from literature studies. This research uses qualitative analysis method, namely the data obtained through research in the field or literature is arranged systematically and then analyzed qualitatively to achieve clarity of the issues to be discussed.

\section{RESULT AND DISCUSSION}

\section{A. Land Use of Protected Areas in TheComal Riparian} Zone and Sragi Lama Riparian Zone

Pemalang Regency is one of thedistricts in Central Java Province which has an area of $1.115,30 \mathrm{~km}^{2}$ with a population in 2016 of 1.292.573 inhabitants. Astronomically, Pemalang Regency is located between $8^{0} 52^{\prime} 30^{\prime \prime}$ - $7^{0} 20^{\prime} 11^{\prime \prime}$ South Latitude and between $109^{0} 17^{\prime} 30^{\prime \prime}$ - 109 $40^{\circ} 30^{\prime \prime}$ East Longitude. Based on its geographical position, Pemalang Regency is directly adjacent to the Java Sea in to the north, Purbalingga Regency in the south, Tegal Regency in the west, and Pekalongan Regency in the east. Pemalang Regency has 4 main rivers which can be describe in the table as follows:

Table 1. Name and Length of The River in Pemalang Regency Year 2016

\begin{tabular}{|c|c|c|c|}
\hline No & Name of The River & $\begin{array}{c}\text { Length } \\
(\mathbf{k m})\end{array}$ & $\begin{array}{l}\text { Region that is traversed } \\
\text { (Sub-District) }\end{array}$ \\
\hline 1 & Comal River & $\begin{array}{l}165,00 \\
(30 \\
\text { creeks })\end{array}$ & $\begin{array}{l}\text { Moga, Randudongkal, } \\
\text { Bantarbolang, Ampelgading, } \\
\text { Comal, Ulujami, and Bodeh. }\end{array}$ \\
\hline 2 & Waluh River & $\begin{array}{l}36,00 \\
(15 \\
\text { creeks })\end{array}$ & $\begin{array}{l}\text { Warungpring, Randudongkal, } \\
\text { Bantarbolang, Pemalang, and } \\
\text { Taman }\end{array}$ \\
\hline 3 & $\begin{array}{l}\text { Rambut River } \\
\text { (border with Tegal } \\
\text { Regency) }\end{array}$ & $\begin{array}{l}57,00 \\
(13 \\
\text { creeks })\end{array}$ & $\begin{array}{l}\text { Moga, Warungpring, and } \\
\text { Pemalang }\end{array}$ \\
\hline 4 & $\begin{array}{l}\text { Sragi Lama River } \\
\text { (border with } \\
\text { Pekalongan } \\
\text { Regency) }\end{array}$ & 8,38 & Ulujami \\
\hline
\end{tabular}

Sumber: Pemalang Regency in Numbers 2017 pg. 292296

Looking at the length of the river as mentioned above, the Comal River is the longest river in Pemalang Regency, which in addition provieds very large benefits can also have a negative impact on the surrounding environment if the use of rivers and surrounding areas neglects the function of riparian zones as a protected area. While the Sragi Lama River is the shortest river in Pemalang Regency which is directly adjacent to Pekalongan Regency on the east side of the river.

Keep in mind that the river is a very important source of water for the community, as in [3] stated that:

Rivers are an essential source of fresh water, which is a vital resource needed for human survival that has no substitutes. Beyond providing water for human consumption, rivers offer the possibility of further benefits ranging from fishing, navigation, irrigation to hydroelectric power generation.

In using the river, bounded by the right and left of the river by riparian lines, [8] explained that riparian zones are 
ecosystems. With the many efforts that have been carried out by the community in the Comal River, this is inversely proportional to the awareness of the community in the Sragi Lama River area, so that the role of Regional Government of Pemalang Regency is needed in its involvement in the field by not denying the cooperation between government agencies and the community in order to achieve riparian zone management as a protected area.

\section{CONCLUSION}

The land in Comal Riparian Zone and Sragi Lama Riparian Zone is used for tree planting, pier for crossing services, public water closet, stallsm building of semipermanent and non-permanent house and landfills. Building resdential houses, stalls and landfills is land use in riparian zones can threaten the damage and deterioration of river quality.

The role of Regional Government of Pemalang Regency and the community in returning the function of riparian zone as protected areas include making a flow rate breaker or gabion, making bamboo embankments, planting trees along Comal Riparian Zone, sowing fish seeds on the Comal River. But unfortunately the government does not pay attention to the Sragi Lama Riparian Zone that enters Pemalang Regency which is sen by the number of residential buildings in the Sragi Lama Riparian Zone so that the role of Regional Government of Pemalang Regency and the community in returning the function of the river as a protected area not maximally carried out in the Sragi Lama Riparian Zone.

\section{ACKNOWLEDGEMENT}

This work was supported by Staff in Infrastructure and Regional Development of Development Planning Agency at Sub-National Level of Pemalang Regency, Section Head of Implementation Water Resources and Section Head of
Implementation Spatial Planning Department of Public Works and Spatial Planning Pemalang Regency, Comal Sub-District, Ulujami Sub-District, People of Comal River Community, and Communities on the Comal Riparian Zone and Sragi Lama Riparian Zone who have helped in the process of research.

\section{REFERENCES}

[1] Arikunto, Suharsimi. (2006). Prosedur Penelitian (Suatu Pendekatan Praktik). Jakarta: Rineka Cipta.

[2] Badan Pusat Statistik Kabupaten Pemalang. (2017) Pemalang Dalam Angka (Pemalang in Figures). Online. Available https://pemalangkab.bps.go.id/publication.html [accessed 01/15/18].

[3] Brochmann, Marit. et al. (2012). International River Treaty Effectiveness. San Diego: Paper presented at the Annual Meeting of the International Studies Association.

[4] Haryanto, Totok Dwinur. (2009). Model Penatagunaan Tanah di Indonesia Berdasarkan Undang-Undang Nomor 5 Tahun 1960. Wacana Hukum 8 (2): 44-55.

[5] Lubis, Riadil Akhir. (2016). Policy Space Utilization in Developing Area Medan-Binjai-Deli Serdang (Mebidang) Indonesia. International Journal of Regional Development 3 (1): 1-17.

[6] Regional Regulaton of Central Java Province No.09 Year 2013 about The Riparian Line.

[7] Regional Regulation of Pemalang Regency No.01 Year 2018 about Spatial Planning of Pemalang Regency Year 2018-2038.

[8] Saifullah. (2016). Formulasi Kebijakan Pelaksana Perlindungan Sempadan Sungai Kabupaten Sukamara. Jurnal Politika 7 (1)

[9] Soekanto, Soerjono. (2007). Faktor-Faktor yang Mempengaruhi Penegakan Hukum. Jakarta: PT Raja Grafindo Persada.

[10] Xin, Xiao-kang, et al. (2015). Evaluation, Prediction, and Protection of Water Quality in Danjiangkou Reservoir, China. International Journal of Water Science and Engineering 8 (1): 30-39. 